\title{
Diel Changes in Predator-Prey Relationships between Red Sea Bream and Gammaridean Amphipods in Shijiki Bay ${ }^{* 1}$
}

\author{
Hiroyuki Sudo, ${ }^{* 2}$ Mikio Azuma, ${ }^{* 3}$ and Masanori Azeta*4
}

(Accepted January 16, 1987)

\begin{abstract}
To explain diel predator-prey interactions between young red sea bream (Pagrus major) and gammaridean amphipods, fish and macrobenthos were collected at $1-4 \mathrm{~h}$ intervals during a $24 \mathrm{~h}$ period from June to July in 1981 and 1983. Young red sea bream showed two feeding peaks, a higher one at dusk and a lower one at dawn, and ceased to feed after dark. Gammarids were the most important food item for the young, but individual species were not taken in proportion to their abundances in the field. The patterns of gammarid selection by the young were related most closely to the microhabitat of gammarid species: Epifaunal and shallow burrowing species were positively selected; infaunal tube-dwelling species were positively or negatively selected with diel time; deep burrowing species were negatively selected. The intensity of predation on Byblis japonicus (infaunal tube-dweller), the most dominant species in the field, was low about noon but increased remarkably at dusk and dawn, whereas that on Synchelidium miraculum lenorostralum (shallow burrower) and Paradexamine marlie (epifauna) increased about noon. This diel dietary shift is caused by diel vertical movements of gammarids, because the vertical movements change their microhabitat and consequently influence the availability of gammarid species.
\end{abstract}

The red sea bream Pagrus major is one of the most important demersal fishes for coastal fisheries in Japan because of its high landings and high market price. This fish is commonly distributed in the seas around Japan and is especially abundant in the western coast of Kyushu. In Shijiki Bay (Hirado Island, Nagasaki Prefecture), a nursery ground for red sea bream is formed in the sandy bottom area of the inner part from June through August., ${ }^{12}$ Azeta et al., ${ }^{12}$ Azuma et al., ${ }^{3)}$ and Sudo and Azetat have already shown that young red sea bream selects gammaridean amphipods as prey and is densely distributed at the sites where gammaridean amphipods are abundant. Omori ${ }^{3)}$ and Imabayashi et al. ${ }^{\text {s) }}$ also reported that gammaridean amphipods were among the most important food items consumed by young red sea bream in Yuya Bay and Seto Inland Sea, respectively. However, they did not identify gammarids to the species level.

Over 100 species of gammarids have been collected in Shijiki Bay, and more than $50 \%$ of these were found in the sandy bottom area of the inner part of the bay. However, only several species of gammarids were commonly found in the stomachs of red sea bream. This fact indicates the importance of species-specific identification of the prey organisms.

Stoner ${ }^{\text {() }}$ stated that prey selection by flsh was related most closely to the microhabitat of prey species. Thus the diverse microhabitat of gammarids $^{8-15)}$ ought to influence the availability of gammarids. Moreover, the availability is expected to change with diel time owing to the occurrence of diel vertical movements of gammarids. ${ }^{16-21)}$

In the present report we explain the predatorprey relationships between young red sea bream and gammarid species, especially with diel changes. We also discuss the factors which influence the gammarid selection by young red sea bream.

*1 Contribution from Seikai Regional Fisheries Research Laboratory, No. 432.

*2 Seikai Regional Fisheries Research Laboratory, 49 Kokubu-machi, Nagasaki 850, Japan (首藤宏幸：酉海 区水産研究所).

*3 Faculty of Education, Nagasaki University, 1-14 Bunkyo-machi, Nagasaki 852, Japan (東 幹夫：長崎大 学教育学部).

*4 Research Division of Fishery Agency, 1-2-1 Kasumigaseki, Chiyoda, Tokyo 100, Japan (畔田正格, 水産 庁研究課). 


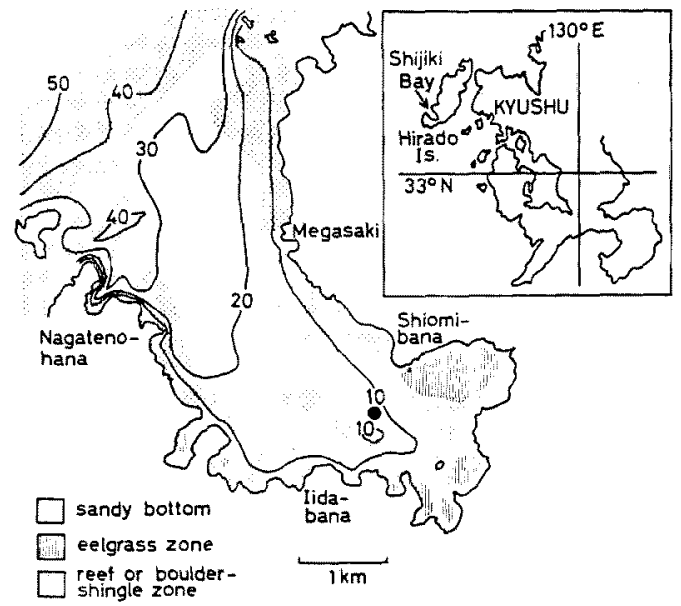

Fig. 1. Map of Shijiki Bay and the sampling site (closed circle). Depth contours are shown in meter.

\section{Materials and Methods}

\section{Field Methods}

Fish and macrobenthos were sampled at a site where young red sea bream was densely distributed in the bay (Fig. 1). Sampling was carried out at $1-4 \mathrm{~h}$ intervals during a $24 \mathrm{~h}$ period from 30 June to 1 July 1981 and from 13 to 14 June 1983 .

Fish were collected with a Gochi trawl ${ }^{1)}$ (3-mm mesh net in the cod end). Macrobenthos were collected with both a NUS-net $(0.5-\mathrm{mm} \text { mesh })^{3)}$ and a Smith-McIntyre grab $\left(0.05 \mathrm{~m}^{2}\right)$. To monitor vertical movements of macrobenthos, 3-layer horizontal tows of $5 \mathrm{~min}$ duration in water column (surface, middle, and bottom layer) were also carried out at 12:00, 20:30, 22:30 and 05:30 from 30 June to 1 July 1981, using a larval net of $0.51-\mathrm{mm}$ mesh size and $1.3-\mathrm{m}$ mouth diameter. Sampling was carried out once at each sampling time except for the Smith-McIntyre grab sampling, which was carried out twice.

Fish captured were preserved in $10 \%$ formalin. Macrobenthic animals retained on $1.0-\mathrm{mm}$ and $0.5-\mathrm{mm}$ mesh screen were preserved in $5 \%$ buffered formalin.

\section{Laboratory Methods}

Twenty stomachs of the red sea bream captured at each sampling time were removed. Stomach contents were classified to major food items as higher taxa such as gammarids, mysids, polychaetes etc., and all food items were counted under a binocular microscope. The percentage contribution of each food item to the total diet was calculated from individual numbers of each food item eaten and mean weight from NUS-net samples. Gammarids, the most important food item for young red sea bream, were examined at the species level. Food data concerning gammarid species were presented as percentage composition, i.e., number of individuals of each gammarid species/total number of gammarids. Dry weight of the stomach contents and of the fish were measured after leaving them at $60^{\circ} \mathrm{C}$ until constant weight was achieved.

After sorting all macrobenthic animals in the sediments, they were identified and counted. In particular, gammarids were identified to the species level and counted.

\section{Results}

Diel Feeding Periodicity of Young Red Sea Bream

Red sea bream as well as hairychin goby (Sagamia geneionema) was the most numerous fish among demersal fishes captured. The total number of the red sea bream captured by 11 hauls was 2355 and 1193 in 1981 and in 1983, respectively. The mean fork length was $50.8 \mathrm{~mm}$ in 1981 and $29.1 \mathrm{~mm}$ in 1983.

The pattern of diel changes in the percentage of the fish with empty stomach in 1981 was similar to that in 1983. It was almost $0 \%$ from 5:30 till 22:00, and thereafter increased to $100 \%$ through the night (Table 1). Diel changes in food uptake of the red sea bream showed two feeding peaks, a higher one at dusk (stomachcontent weight per body weight: $2.2 \%$ in 1981 ; $3.3 \%$ in 1983) and a lower one at dawn $(1.3 \%$ in $1981 ; 2.0 \%$ in 1983), as shown in Fig. 2. Stomachcontent weight per body weight exponentially decreased to $0 \%$ through the night. Taking account of the gastric evacuation rate from the starvation experiment,* we can conclude that young red sea bream starts to feed at dawn and ceases to feed after dark.

Gammarids, mysids, caprellids, polychaetes and fish eggs were main food items. Of these food items, gammarids made up the largest portion $(20.2 \%-61.1 \%$ in $1981 ; 27.2 \%-65.9 \%$ in 1983$)$. The uptake of gammarids by young red sea bream had a higher peak at dusk and a lower one at dawn. Up to 66 and 31 gammarids were de-

* M. Azeta, R. Ikemoto, H. Sudo, and M. Azuma: Abstract of the annual meeting of the Japan. Soc. Sci. Fish., Kyoto, p. 75 (1983). 
Table 1. Number of red sea bream caught and empty stomach rate*

\begin{tabular}{|c|c|c|c|c|c|}
\hline \multicolumn{3}{|c|}{ 30 June-1 July 1981} & \multicolumn{3}{|c|}{ 13-14 June 1983} \\
\hline Sampling time & No. caught & $\begin{array}{c}\text { Empty stomach } \\
(\%)\end{array}$ & Sampling time & No. caught & $\begin{array}{c}\text { Empty stomach } \\
(\%)\end{array}$ \\
\hline $08: 26-08: 38$ & 839 & 0 & $17: 11-17: 26$ & 31 & 0 \\
\hline $11: 22-11: 36$ & 280 & 0 & $19: 10-19: 24$ & 52 & $\mathbf{0}$ \\
\hline $14: 17-14: 28$ & 77 & 0 & $20: 00-20: 20$ & 27 & 0 \\
\hline $16: 46-16: 57$ & 387 & 0 & $21: 58-22: 18$ & 109 & 0 \\
\hline $18: 47-18: 57$ & 163 & 0 & $01: 03-01: 21$ & 111 & 80 \\
\hline $19: 50-20: 02$ & 27 & 0 & $04: 35-04: 49$ & 210 & 100 \\
\hline $22: 43-23: 00$ & 208 & 55 & $05: 35-05: 47$ & 23 & 20 \\
\hline $02: 38-02: 54$ & 44 & 100 & $06: 59-07: 10$ & 214 & 0 \\
\hline $04: 29-04: 43$ & 26 & 100 & $08: 56-09: 10$ & 88 & 0 \\
\hline $05: 27-05: 43$ & 153 & 10 & $11: 57-12: 10$ & 139 & 0 \\
\hline $06: 26-06: 39$ & 151 & 0 & $15: 01-15: 13$ & 189 & 0 \\
\hline
\end{tabular}

* Empty stomach rate $=\frac{\text { Number of fish with empty stomach }}{\text { Number of fish examined }} \times 100$

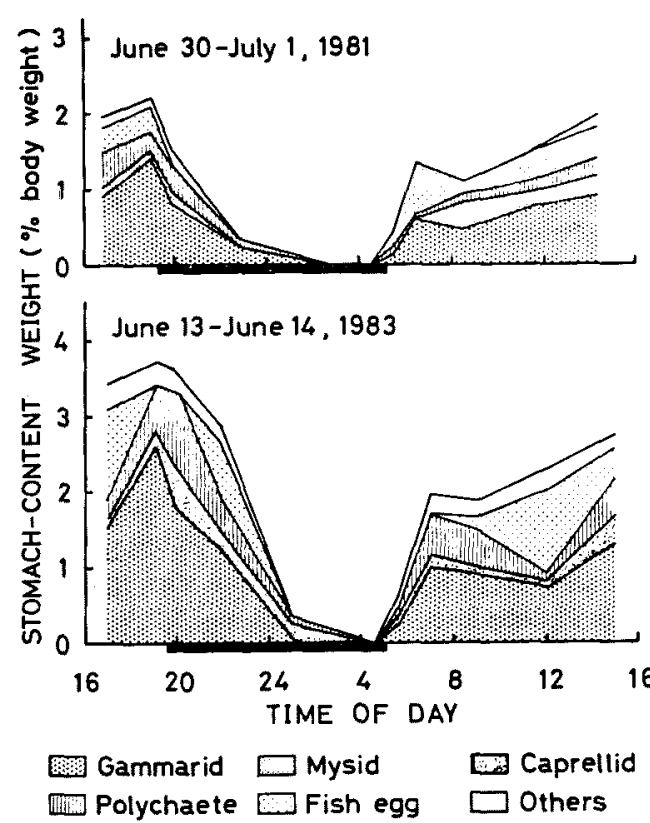

Fig. 2. Diel changes in food composition of young red sea bream. Black bars represent hours of darkness.

tected in one stomach in 1981 (from a fish of 57.1-mm fork length) and in 1983 (from a fish of 34.6-mm fork length), respectively.

\section{Gammarid Species in the Field}

Table 2 shows all gammarid species collected at the study site in 1981 and 1983. A series of reports on taxonomic studies of gammaridean amphipods in west Kyushu including Shijiki Bay has been published by Hirayama. ${ }^{2-34}$ In his reports, many new species have been recorded.
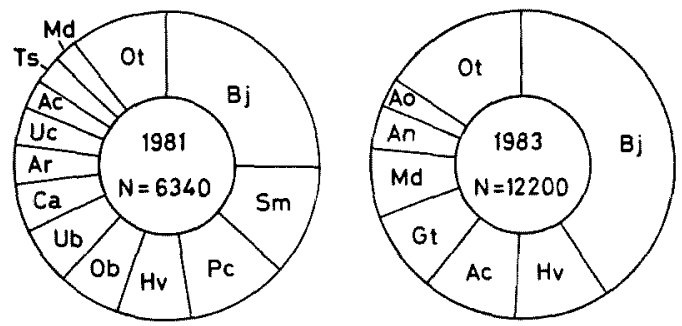

Fig. 3. Composition of gammarid species at the study site. $\mathrm{N}=$ number of gammarids $(>0.5$ $\mathrm{mm})$ per square meter. Bj: Byblis japonicus; Sm: Synchelidium miraculum lenorostralum; Pc: Protomedeia crudoliops; Hv: Harpiniopsis sp.; Ac: Aoroides columbiae; Ob: Orchomene breviceps; Ub: Urothoe sp. B; Ca: Colomastix azumai; Ar: Ampelisca brevicornis; Uc: Urothoe sp. C; Ts: Tiron sp.; Md: Melita denticulata; Gt: Guernea terelamina; An: Ampelisca naikaiensis; Ao: Ampelisca bocki; Ot: Others.

Thus, we identified gammarid species in Shijiki Bay mainly based on his reports. According to microhabitat information given in the literature $^{9-15,35)}$ and by Hirayama (personal communication), we classified gammarids into 4 types by their microhabitats: (1) epifauna (including commensal, tube-dwelling, nestling and free living species); (2) shallow burrower; (3) infaunal tubedweller; (4) deep burrower.

Fig. 3 shows species composition of gammarids collected at the study site. Since the SmithMcIntyre grab was the most efficient sampler for gammarids of all samplers used in this study and a large number of gammarids moved up to the water column at night, results obtained by SmithMcIntyre grab samplings during daytime are 
Table 2. Gammarid species collected at the study site and their microhabitat types. EF: epifauna; IT: infaunal tube-dweller; SB: shallow burrower; DB: deep burrower

\begin{tabular}{|c|c|c|c|}
\hline Species & $\begin{array}{l}\text { Micro- } \\
\text { habitat }\end{array}$ & Species & $\begin{array}{l}\text { Micro- } \\
\text { habitat }\end{array}$ \\
\hline Family Acanthonotozomatidae & & Family Ischyroceridae & \\
\hline Cypsiphimedia mala & EF & Cerapus tubularis & $\mathrm{EF}$ \\
\hline Postodius sp. & EF & Ericthonius pugnax & EF \\
\hline Family Ampeliscidae & & Jassa falcata & $\mathrm{EF}$ \\
\hline Ampelisca bocki & IT & Family Leucothoidae & \\
\hline Ampelisca brevicornis & IT & Leucothoe bidens & $\mathrm{EF}$ \\
\hline Ampelisca miharaensis & IT & Family Liljeborgiidae & \\
\hline Ampelisca naikaiensis & IT & Liljeborgia serrata & $\mathrm{EF}$ \\
\hline Byblis japonicus & IT & Family Lysianassidae & \\
\hline Family Amphilochidae & & Hippomedon pacificus & SB \\
\hline Cyproidea liodactyla & $\mathrm{EF}$ & Lepidepecreum vitjazi & SB \\
\hline Gitanopsis breviculus & EF & Orchomene breviceps & SB \\
\hline Gitanopsis japonica & EF & Orchomene liomargo & SB \\
\hline Gitanopsis longus & $\mathrm{EF}$ & Family Melitidae & \\
\hline Terepeltopes dolichorhunia & $\mathrm{EF}$ & Melita denticulata & EF \\
\hline Family Ampithoidae & & Melita japonica & $\mathrm{EF}$ \\
\hline Ampithoe lacertosa & EF & Melita sp. & $\mathrm{EF}$ \\
\hline Ampithoe pollex & $\mathrm{EF}$ & Family Oedicerotidae & \\
\hline Perampithoe orientalis & EF & Perioculodes longimanus & SB \\
\hline Family Atylidae & & Synchelidium miraculum lenorostralum & SB \\
\hline Atylus japonicus & EF & Family Phliantidae & \\
\hline Family Colomastigidae & & Palinnotus sp. & $\mathrm{EF}$ \\
\hline Colomastix azumai & EF & Family Phoxocephalidae & \\
\hline Family Corophiidae & & Harpiniopsis miharaensis & $\mathrm{DB}$ \\
\hline Aoroides columbiae & $\mathrm{EF}$ & Harpiniopsis sp. & $\mathrm{DB}$ \\
\hline Corophium acherusicum & IT & Metaphoxus sp. & DB \\
\hline Corophium crassicorne & IT & Paraphoxus sp. & DB \\
\hline Corophium insidiosum & IT & Family Pleustidae & \\
\hline Corophium kitamorii & IT & Parapleustes bicuspoides & $\mathrm{EF}$ \\
\hline Gammaropsis japonicus & IT & Parapleustes sp. & $\mathrm{EF}$ \\
\hline Gammaropsis utinomii & IT & Pleustes panoplus & EF \\
\hline Protomedeia crudoliops & IT & Family Podoceridae & \\
\hline Family Dexaminidae & & Podocerus sp. & $\mathrm{EF}$ \\
\hline Guernea terelamina & $\mathrm{EF}$ & Family Stenothoidae & \\
\hline Guernea sp. & EF & Stenothoe sp. & $\mathrm{EF}$ \\
\hline Paradexamine bisetigera & $\mathrm{EF}$ & Family Synopiidae & \\
\hline Paradexamine marlie & EF & Tiron sp. & EF \\
\hline Polychelia atolli orientalis & EF & Family Urothoidae & \\
\hline Family Eusiridae & & Urothoe sp. A & DB \\
\hline \multirow[t]{2}{*}{ Pontogeneia rostrata } & $\mathrm{EF}$ & Urothoe sp. B & DB \\
\hline & & Urothoe sp. C & DB \\
\hline
\end{tabular}

represented in Fig. 3 (14:00 in 1981; 12:00 in 1983). The number of gammarids $(>0.5 \mathrm{~mm}$ ) was $6340 / \mathrm{m}^{2}$ in 1981 and $12200 / \mathrm{m}^{2}$ in 1983 . The number of individuals collected on the $1.0-\mathrm{mm}$ screen accounted for $45.5 \%$ and $28.2 \%$ of the number retained by the $0.5-\mathrm{mm}$ mesh in 1981 and 1983, respectively. In both 1981 and 1983 Byblis japonicus was the most abundant species (24.4\% of the total gammarids in $1981 ; 40.2 \%$ in
1983). Synchelidium miraculum lenorostralum and Protomedeia crudoliops comprised individually more than $10 \%$ of the total in 1981 , and Harpiniopsis sp. and Aoroides columbiae individually contributed over $10 \%$ in 1983 . Byblis japonicus appears to make up a larger portion of the total gammarids in biomass rather than in number because of the large body size of this species. 


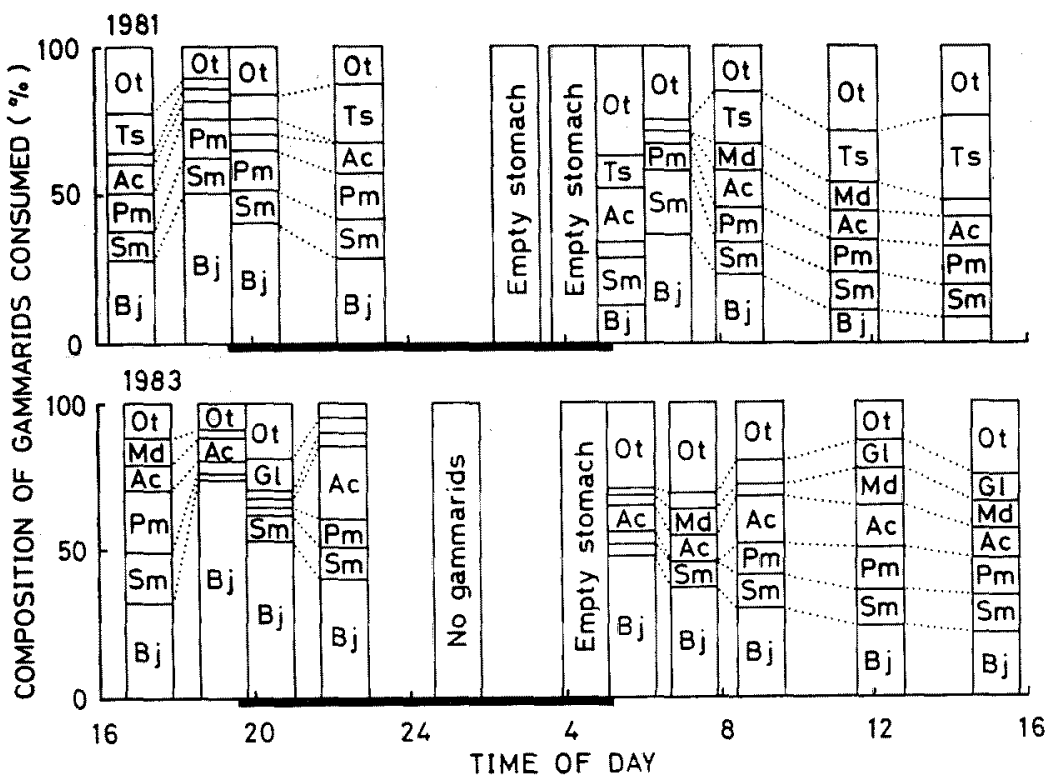

Fig. 4. Diel changes in percentage composition of gammarid species consumed by young red sea bream. Black bars represent hours of darkness. Bj: Byblis japonicus; $\mathrm{Sm}$ : Synchelidium miraculum lenorostralum; Pm: Paradexamine marlie; Ac: Aoroides columbiae; Md: Melita denticulata; Ts: Tiron sp.; Gl: Gitanopsis longus; Ot: Others.

Gammarid Species in the Stomachs

As shown in Table 2, about 60 species of gammarids were collected at the study site. About $50 \%$ of these occurred in stomachs of young red sea bream: 34 species ( 15 families and 26 genera) and 32 species (16 families and 24 genera) were found in the stomachs in 1981 and 1983, respectively; 27 species (14 families and 22 genera) were found in both 1981 and 1983. However, only seven species surpassed $10 \%$ of the gammarids consumed in at least one sampling time. Those were Byblis japonicus, Synchelidium miraculum lenorostralum, Paradexamine marlie, Aoroides columbiae, Melita denticulata and Tiron sp. in 1981 (six species), and Byblis japonicus, Synchelidium miraculum lenorostralum, Paradexamine marlie, Aoroides columbiae, Melita denticulata and Gitanopsis longus in 1983 (six species). The proportion of these species to the total gammarids ranged from $61.8 \%$ to $88.2 \%$ in 1981 and from $68.6 \%$ to $94.7 \%$ in 1983 with diel time (Fig. 4). Of these species, Byblis japonicus was the most frequently consumed species in both 1981 and 1983. Furthermore, it showed the largest body length (Fig. 5). Thus Byblis japonicus was the most important gammarid species consumed by young red sea bream. Synchelidium miraculum lenorostralum, Paradexamine marlie and Melita

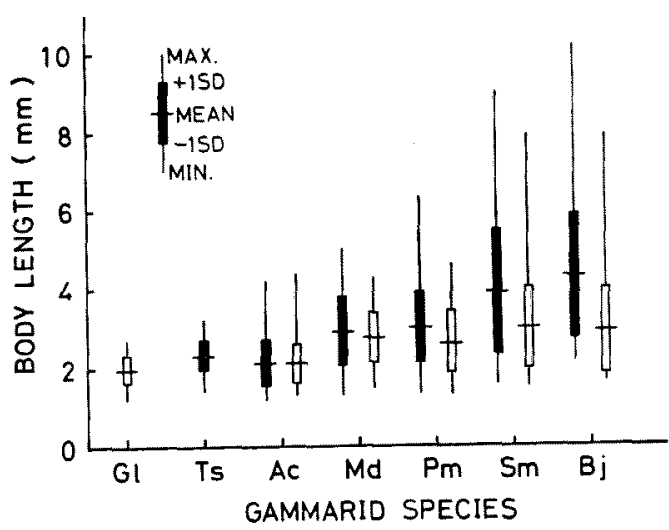

Fig. 5. Body length (from the rostrum to the tip of telson) of common gammarid species in stomachs of young red sea bream. Black bars and white bars indicate 1981 and 1983, respectively. Abbreviations representing gammarid species as in Fig. 4.

denticulata were also important food species, because of their high frequency of occurrence and large body size. Aoroides columbiae, Tiron sp. and Gitanopsis longus were the less important food species of these seven gammarid species, because of their smaller body size.

Comparing the relative abundance of gammarid species in the stomachs with that in the field, 


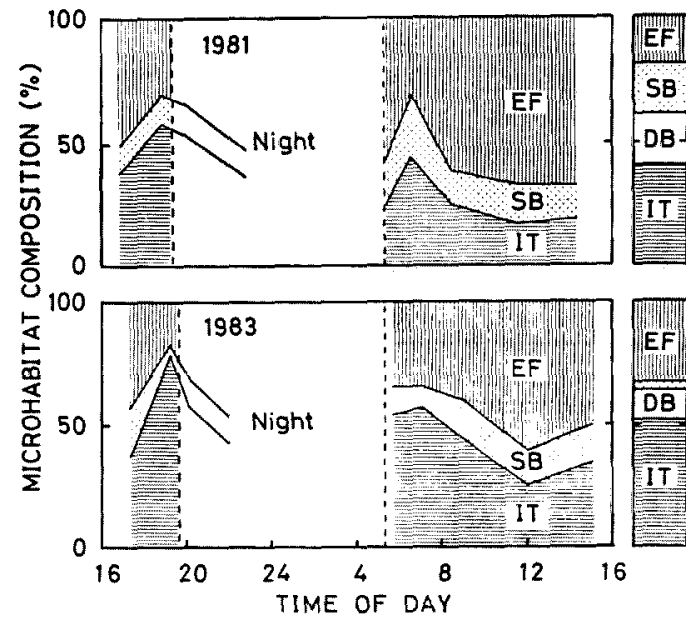

Fig. 6. Diel changes in microhabitat composition of gammarids in stomachs of young red sea bream. The right bars show microhabitat composition of gammarids in the field. EF: epifauna; SB: shallow burrower; DB: deep burrower; IT: infaunal tube-dweller.

individual gammarid species were not taken in proportion to their abundances in the field. The patterns of gammarid selection by young red sea bream correlated with the microhabitat of gammarid species. Infaunal tube-dwelling species such as Byblis japonicus were positively or negatively selected as prey with diel time. Shallow burrowing species such as Synchelidium miraculum lenorostralum, and epifaunal species such as Paradexamine marlie, Aoroides columbiae, Melita denticulata, Tiron sp. and Gitanopsis longus were positively selected. Deep burrowing species such as Harpiniopsis sp., Urothoe sp. B and Urothoe sp. C were negatively selected. However, there were diel changes in predation patterns on gammarids: (1) infaunal tube-dwelling species were subjected to heavy predation at dusk and dawn; (2) epifaunal species were subjected to heavy predation about noon; (3) shallow burrowing species were subjected to constant predation; (4) deep burrowing species were hardly subjected to predation all day (Fig. 6).

This diel dietary shift of young red sea bream was not caused by changes in feeding behavior of the fish but was caused by vertical movements of gammarids. Fig. 7 shows diel predation patterns on three gammarid species heavily consumed by young red sea bream and vertical movement patterns of these three gammarid species. Byblis japonicus, an infaunal tube-dwelling species, lives in the tube in the daytime; however, this species
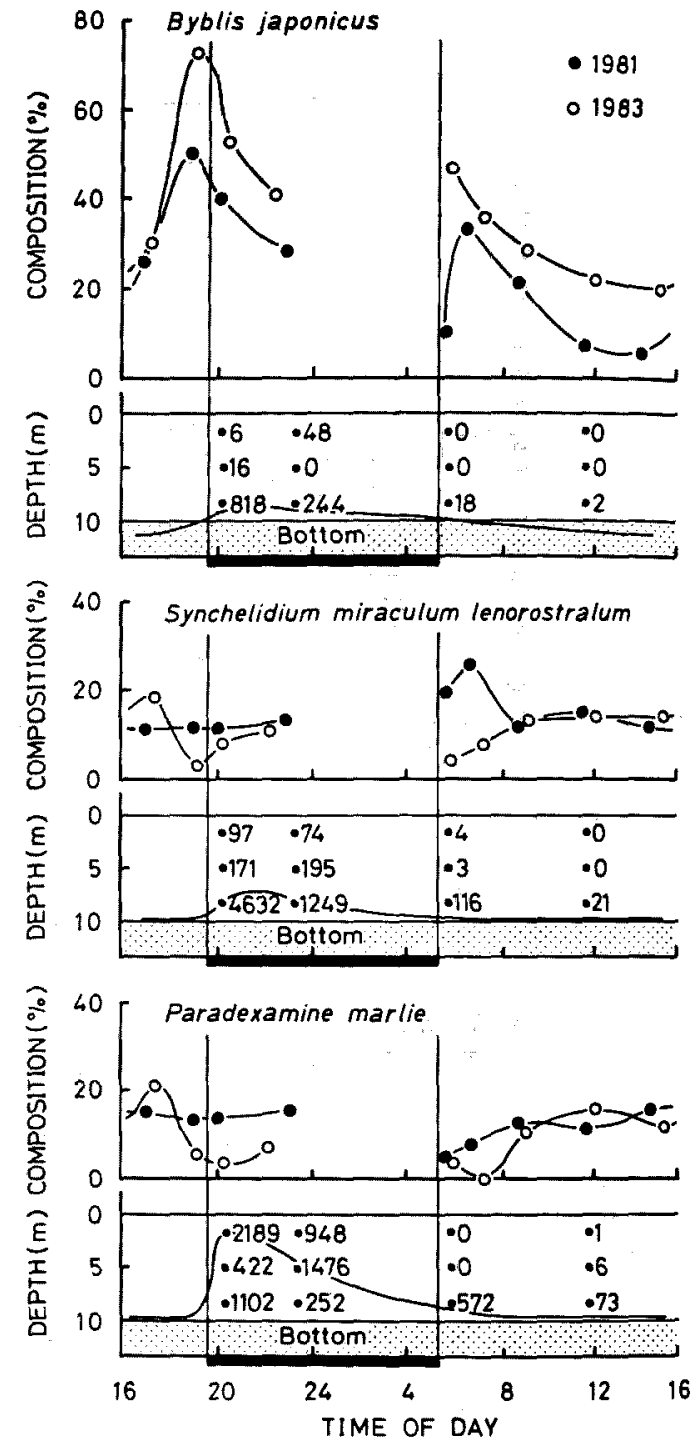

Fig. 7. Diel predation patterns on three gammarid species heavily consumed by young red sea bream (upper) and diel vertical movement patterns of each gammarid species (lower). Black bars represent hours of darkness. Numerals in the figure show the number of each gammarid species collected by one horizontal tow of larval net in water column.

comes up to the bottom surface in large numbers from dusk to dawn. Synchelidium miraculum lenorostralum, a shallow burrowing species, digs in the superficial bottom sand exposing the dorsal part of the cephalon and of the thorax above the bottom surface in the daytime but swims up to the water column near the bottom in large numbers from dusk to dawn. Paradexamine marlie, an 
epifaunal species, lives freely on the bottom surface in the daytime but swims up to the water column near the surface in large numbers from dusk to dawn. On the other hand, the intensity of predation on Byblis japonicus was low about noon but increased remarkably at dusk and dawn, whereas that on Synchelidium miraculum lenorostralum or Paradexamine marlie increased about noon. Taking account of (1) the feeding time of young red sea bream, (2) the difference in availability among each microhabitat types of gammarids and (3) the vertical movement patterns of each gammarid species, we can explain these diel changes in the intensity of predation as follows:

In the daytime young red sea bream cannot feed fully on Byblis japonicus, the most dominant species of gammarids in the field, because this gammarid lives in the tube (endobenthic) in the daytime. However, it can feed heavily on Byblis japonicus at dusk and dawn, because this gammarid comes up to the bottom surface (epibenthic) from dusk to dawn (young red sea bream ceases to feed after dark). On the other hand, it can feed on Synchelidium miraculum lenorostralum and Paradexamine marlie in the daytime, because both gammarids live on the bottom surface (epibenthic) even in the daytime.

\section{Discussion}

We described in this paper that about $50 \%$ of gammarid species occurring at the study site were used as prey by young red sea bream; moreover, common gammarids consumed were only several species. These data demonstrate the importance of discriminating the "true" prey species for studies on predator-prey relationships. Speciesby-species comparison between organisms in the stomachs and those in the field is essential to this discrimination, although few researchers identify prey organisms to the species level. Furthermore, patterns of food partitioning among fishes often become obscure without species identification of prey organisms. ${ }^{38)}$ Since gammarids, the most important food item for young red sea bream, have various life style depending on species, accurate information on feeding behavior of the fish can be also given by the identification of gammarid species in the stomachs. Thus, as asserted by Stoner," the researchers who conduct feeding studies are required to be familiar with the taxonomy of the prey organisms.

We pointed out in this paper that young red sea bream ceases to feed after dark, judging from both its decrease in stomach-content weight per body weight and its gastric evacuation rate. This is also supported by our underwater observations. After dark, young red sea bream separated into solitary individuals and rested quietly in the hollow of sandy bottom. In the daytime, however, it hovered about near the bottom and pecked at benthic animals when recognizing them. The daytime activity mode gradually shifted toward the nighttime one during dusk; the reverse shift was observed during dawn. Young red sea bream in Shijiki Bay showed two feeding peaks at dusk and dawn. The time of these two feeding peaks consequently coincided with the time when prey organisms available to young red sea bream were abundant.

The difference between species composition of gammarids in the stomachs and that in the field is expected to be due to the difference in availability of each gammarid species. Stoner ${ }^{r)}$ pointed out that amphipod selection by the pinfish Lagodon rhomboides was related most closely to the microhabitat of amphipod species and important prey species were all epifaunal types. In our study, the patterns of gammarid selection by young red sea bream also correlated with the microhabitat of prey species. Both epifaunal (e.g., Paradexamine marlie) and shallow burrowing types (e.g., Synchelidium miraculum lenorostralum) were positively selected as prey, although the degree of selectivity for epifaunal species was higher than that for shallow burrowing species. Infaunal tube-dwelling types (e.g., Byblis japonicus) were positively or negatively selected with diel time. Deep burrowing types (e.g., Harpiniopsis sp., Urothoe sp. B and Urothoe sp. C) were negatively selected or hardly consumed. These results indicate that the availability of gammarid species increases with the decrease of gammarid livingdepth in the sediment. This finding is consistent with our underwater observations that young red sea bream, a visual feeder, normally swims off the bottom and pecks at prey organisms only when recognizing them. We did not observe the young burrowing in or stirring up the sediment.

However, there were diel changes in the pattern of predation on gammarid species by young red sea bream. The intensity of predation on Byblis japonicus was low about noon but increased remarkably at dusk and dawn, whereas that on Synchelidium miraculum lenorostralum and Paradexamine marlie increased about noon. This diel dietary shift is caused by diel vertical movements of 
gammarids, because vertical movements change their microhabitat and consequently influence their availability. Young red sea bream cannot feed fully on Byblis japonicus in the daytime, when this gammarid is in the tube; however, it can feed heavily on Byblis japonicus at dusk and dawn, when this gammarid comes up to the bottom surface or to the water column near the bottom in large numbers. On the other hand, it can feed on Synchelidium miraculum lenorostralum and Paradexamine marlie in the daytime, when both gammarids live on the bottom surface. Thus the diel dietary shift of young red sea bream does not contradict the results that epibenthic gammarids are most available. However, once gammarids come up to the bottom surface, their abundance, body size, and moving speed (swimming or crawling) appear to become major factors influencing prey selectivity. In fact, Byblis japonicus, which was more abundant, larger in body length, and slower in movement (judging from its body shape and type of appendages ${ }^{11}$ ), was subjected to heavier predation by young red sea bream than the other two species when it came up to the bottom surface.

\section{Acknowledgments}

We are particularly grateful to Dr. A. Hirayama of Asia University and Dr. T. Kikuchi of Kyushu University for guidance in the identification of gammarids and advice on the microhabitat of gammarids. We would like to thank Dr. M. Tanaka of Kyoto University, Dr. Y. Matsumiya of Nagasaki University, Mr. T. Matsuda, Mrs. N. Tanaka, and the students of Kyoto University and of Nagasaki University for assistance in field collections and processing of samples. We also acknowledge valuable discussions with Dr. S. Sato.

\section{References}

1) M. Azeta, R. Ikemoto, and M. Azuma: Bull. Seikai Reg. Fish. Res. Lab., 54, 259-278 (1980).

2) H. Sudo, R. Ikemoto, and M. Azeta: Bull. Seikai Reg. Fish. Res. Lab., 59, 71-84 (1983).

3) M. Azuma, M. Azeta, and K. Mitsumaru: Bull. Seikai Reg. Fish. Res. Lab., 59, 101-118 (1983).

4) H. Sudo and M. Azeta: Bull. Int. North Pac. Fish. Comm., 47, 129-141 (1986).

5) M. Omori: Bull. Seikai Reg. Fish. Res. Lab., 54, 93-109 (1980).

6) H. Imabayashi, T. Hanaoka, and S. Takamori:
Bull. Nansei Reg. Fish. Res. Lab., 8, 101-111 (1975).

7) A. W. Stoner: Mar. Biol., 55, 201-207 (1979).

8) J. L. Barnard: Smithson. Contr. Zool., 34, 1286 (1970).

9) J. L. Barnard: Micronesica, 12, 169-181 (1976).

10) C. K. Biernbaum: J. exp. mar. Biol. Ecol,, 38, 201-223 (1979).

11) E. L. Bousfield: Shallow-water gammaridean Amphipoda of New England, Cornell University Press, Ithaca, New York, 1973, pp. 1-312.

12) P. Enequist: Zool. Bidrag fran Uppsala, 28, 297492 (1949).

13) R. J. Lincoln: British marine Amphipoda: Gammaridea, Publ. No. 818, British Museum (Natural History), London, 1979, pp. 1-658.

14) A.W. Stoner: Bull. Mar. Sci., 30, 537-551 (1980).

15) Y. Wakabara, E. Kawakami, and A. S. Tararam: Mar. Biol., 68, 67-70 (1982).

16) A. L. Alldredge and J. M. King: J. exp. mar. Biol. Ecol., 44, 133-156 (1980).

17) A. L. Alldredge and J. M. King: Mar. Biol., 84, 253-260 (1985).

18) A. A. Fincham: J. mar. biol. Ass. U. K., 50, 177-198 (1970).

19) E. S. Hobson and J. R. Chess: Fish. Bull., 74, 567-598 (1976).

20) E. L. Mills: J. Fish. Res. Board Canada, 24, 305-355 (1967).

21) A. I. Robertson and R. K. Howard: Mar. Biol., 48, 207-213 (1978).

22) A. Hirayama: Publ. Seto Mar. Biol. Lab., 25, 131-156 (1980).

23) A. Hirayama: Publ. Seto Mar. Biol. Lab., 28, $75-150$ (1983).

24) A. Hirayama: Publ. Seto Mar. Biol. Lab., 29, 1-92 (1984).

25) A. Hirayama: Publ. Seto Mar. Biol. Lab., 29, 187-230 (1984).

26) A. Hirayama: Publ. Seto Mar. Biol. Lab., 30, 1-53 (1985).

27) A. Hirayama: Publ. Seto Mar. Biol. Lab., 30, 167-212 (1985).

28) A. Hirayama: Publ. Seto Mar. Biol. Lab., 31, 1-35 (1986).

29) A. Hirayama: Publ. Amakusa Mar. Biol. Lab., 4, 235-243 (1978).

30) A. Hirayama: Publ. Amakusa Mar. Biol. Lab., 4, 245-251 (1978).

31) A. Hirayama: Zool. Sci., 3, 357-366 (1986).

32) A. Hirayama and T. Kikuchi: Publ. Amakusa Mar. Biol. Lab., 5, 67-77 (1979).

33) A. Hirayama and T. Kikuchi: Publ. Amakusa Mar. Biol. Lab., 5, 133-141 (1980).

34) A. Hirayama and T. Kikuchi: Publ. Amakusa Mar. Biol. Lab., 5, 143-151 (1980).

35) Y. Matsumiya, T. Koguchi, and H. Sudo: Bull. 
Fac. Fish. Nagasaki Univ., 60, 41-51 (1986).

11, 257-266 (1977).

36) M. Kislalioglu and R. N. Gibson: I. Fish Biol, 